\title{
Analysis of Pleiotropic Effects of Nivolumab in Pretreated Advanced or Recurrent Non-small Cell Lung Cancer Cases
}

\author{
YUMIKO AKANO $^{1 *}$, KOZO KURIBAYASHI $^{1,2^{*}}$, NORIHIKO FUNAGUCHI ${ }^{3}$, \\ YUICHI KODA ${ }^{1}$, ERIKO FUJIMOTO ${ }^{1}$, KOJI MIKAMI ${ }^{1}$, TOSHIYUKI MINAMI $^{1}$, \\ RYO TAKAHASHI ${ }^{1}$, TAKASHI YOKOI ${ }^{1,2}$ and TAKASHI KIJIMA ${ }^{1,2}$ \\ ${ }^{1}$ Department of Internal Medicine, Division of Respiratory Medicine, \\ ${ }^{2}$ Department of Thoracic Oncology, Hyogo College of Medicine, Hyogo, Japan; \\ ${ }^{3}$ Department of Respiratory Medicine, Asahi University Hospital, Gifu, Japan
}

\begin{abstract}
Background/Aim: Nivolumab is an immune checkpoint inhibitor for advanced non-small cell lung cancer (NSCLC). We investigated the safety and efficacy of nivolumab by analyzing the response factor, adverse effects $(A E)$, and the post-treatment condition of pretreated advanced or recurrent NSCLC patients. Patients and Methods: Nivolumab $(3 \mathrm{mg} / \mathrm{kg})$ was administered to 79 pre-treated NSCLC patients from December 2015 to January 2018. Nivolumab efficacy and $A E$ were assessed using the Response Evaluation Criteria in Solid Tumors and the Common Terminology Criteria, respectively. Results: Progression-free survival (PFS) was significantly prolonged in cases where the therapeutic effect of the pretreatment was a partial response $(p=0.0004)$. Five cases (6.3\%) experienced grade 3-4 AEs. PFS was significantly prolonged in the skin rash group versus the non-skin rash group, and in patients where nivolumab treatment was discontinued. Conclusions: Long-term survival was observed in patients with skin rash. Therapeutic effect of nivolumab immediately following its administration appears to be favorable for survival.
\end{abstract}

Nivolumab is the first immune checkpoint inhibitor developed in Japan for advanced non-small cell lung cancer (NSCLC) (1). It is an antibody against programmed cell

This article is freely accessible online.

*These Authors contributed equally to this study.

Correspondence to: Kozo Kuribayashi, Division of Respiratory Medicine, Department of Internal Medicine, Hyogo College of Medicine, 1-1 Mukogawa-cho, Nishinomiya, Hyogo 663-8501, Japan. Tel: +81 798456596, Fax: +81 798456597, email: kuririn@hyo-med.ac.jp

Key Words: Immune checkpoint inhibitor, immune-related adverse event, nivolumab, non-small cell lung cancer, programmed cell death ligand 1 , durable response. death 1 (PD-1), which blocks the binding of PD-1 to PDligand 1 (PD-L1) and PD-L2 receptors and suppresses tumor proliferation by activating cancer antigen-specific T-cells and increasing their cytotoxic activity (2). While chemotherapy is generally used as a first-line treatment for NSCLC (3), Carbone $e t$ al. reported a better safety profile for Nivolumab when used as a first line treatment (4). The CheckMate 017 trial on squamous cancer (5) and the CheckMate 057 trial on non-squamous cancer (6) found a significant increase in the overall survival (OS) period in the group treated with nivolumab compared to the docetaxel group. These results have also been validated in the Japanese Phase II trial ONO4538-05 for squamous cancer (7) and the ONO-4538-06 trial for non-squamous cancer (8), with response rates of $25.7 \%$ and $19.7 \%$, respectively. New insights on the predictive effects of immune-related adverse events (irAE) of therapy with immune checkpoint inhibitors are emerging from largescale clinical trials (9) and the important role of nivolumab as a chemotherapeutic agent for NSCLC (10).

One feature of nivolumab is that it offers a clinical paradigm shift in the treatment of lung cancer, largely because of its efficacy in squamous cancer of smokers for whom treatment choices have hitherto been limited (11). This study aimed to corroborate previous findings and further elucidate the safety and efficacy of nivolumab in clinical settings.

\section{Patients and Methods}

This study was approved by the Institutional Ethics Review Board of Hyogo College of Medicine, Japan and complies with the 2013 Helsinki Declaration. The requirement for informed consent was waived for this retrospective study.

Patients. Intravenous Nivolumab ( $3 \mathrm{mg} / \mathrm{kg}$ ) was administered to 79 patients (58 males and 21 females) with pretreated advanced or recurrent NSCLC every 2 weeks over a 6-week cycle, until radiographic disease progression, unacceptable toxicity, or withdrawal was confirmed. Safety 
Table I. Demographics and baseline characteristics of patients included in the present study.

\begin{tabular}{|c|c|c|}
\hline Baseline characteristics $(\mathrm{N}=79)$ & $\mathrm{N}$ & $\%$ \\
\hline \multicolumn{3}{|l|}{ Age, years } \\
\hline Median & 70 & \\
\hline Range & $41-86$ & \\
\hline$<75$ & 57 & 72.2 \\
\hline$\geq 75$ & 22 & 27.8 \\
\hline \multicolumn{3}{|l|}{ Gender } \\
\hline Male & 58 & 73.4 \\
\hline Female & 21 & 26.6 \\
\hline \multicolumn{3}{|l|}{ Smoking status } \\
\hline Never & 12 & 15.2 \\
\hline Former/Current & 67 & 84.8 \\
\hline \multicolumn{3}{|l|}{ ECOG PS } \\
\hline 0 & 15 & 19 \\
\hline 1 & 47 & 59.5 \\
\hline 2 & 15 & 19 \\
\hline 3 & 2 & 2.5 \\
\hline \multicolumn{3}{|l|}{ Histology } \\
\hline Adenocarcinoma & 43 & 54.4 \\
\hline Squamous cell carcinoma & 32 & 40.5 \\
\hline Adenosquamous & 1 & 1.3 \\
\hline NOS & 1 & 1.3 \\
\hline Pleomorphic carcinoma & 2 & 2.5 \\
\hline \multicolumn{3}{|l|}{ Stage } \\
\hline IIA & 1 & 1.3 \\
\hline IIIA & 11 & 13.9 \\
\hline IIIB & 13 & 15.5 \\
\hline IV & 39 & 49.4 \\
\hline Recurrence & 15 & 19 \\
\hline \multicolumn{3}{|l|}{ Response to Prior chemotherapy } \\
\hline $\mathrm{PR}$ & 34 & 43 \\
\hline $\mathrm{SD}$ & 30 & 38 \\
\hline $\mathrm{PD}$ & 15 & 19 \\
\hline \multicolumn{3}{|l|}{ Driver mutation } \\
\hline \multicolumn{3}{|l|}{ EGFR mutation } \\
\hline Positive & 7 & 8.9 \\
\hline Wild type or unknown & 72 & 91.1 \\
\hline
\end{tabular}

ECOG PS, Eastern cooperative oncology group performance status; EGFR, epidermal growth factor receptor; PD, progressive disease; PR, partial response; SD, stable disease.

was evaluated using the severity of adverse events (AE) and efficacy was assessed using the Response Evaluation Criteria in Solid Tumors (RECIST), version 1.1 (12). Treatment was maintained in the absence of unacceptable side effects, provided that the patients were receiving clinical benefits.

Assessment of efficacy. Tumor response was assessed according to the RECIST guidelines, version 1.1 (12). The primary endpoint was the confirmed overall response rate (ORR). Secondary endpoints included progression-free survival (PFS), overall survival (OS), and disease control rate.

Assessment of safety. The National Cancer Institute's Common Terminology Criteria for Adverse Events, version 4.0 (13) was used to rate the AE during the study.

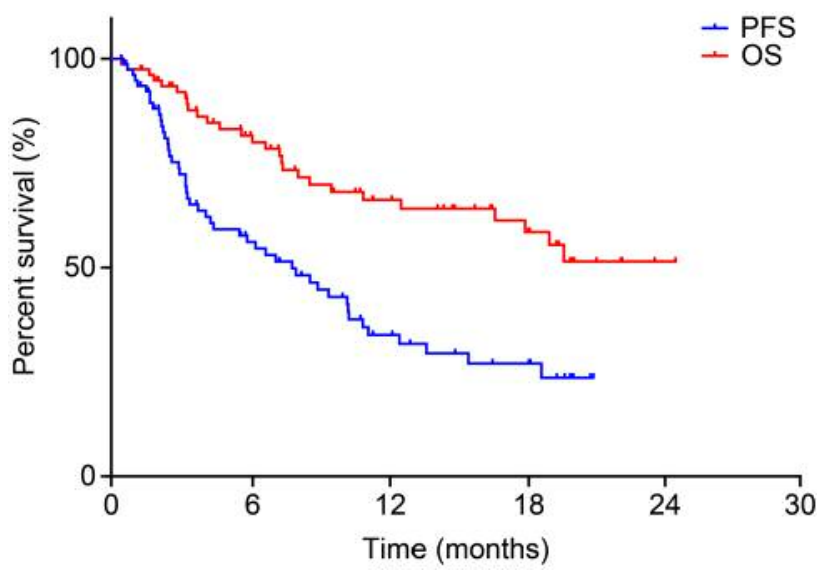

Figure 1. Kaplan-Meier curve for median progression-free survival $(P F S)$ and overall survival (OS) across all cases.

Subgroup analysis. A prespecified subgroup analysis for ORR and a post hoc subgroup analysis for PFS and OS were performed to determine the association between the efficacy variables and patients' sex, age, histological subtype, treatment regimen, Eastern Cooperative Oncology Group performance status (ECOG PS), smoking status, the therapeutic effect of the pretreatment, and possible mutations in the epidermal growth factor receptor $(E G F R)$ gene.

PD-L1 analysis. Tumor PD-L1 expression was evaluated in pretreated (old or recent) tumor-biopsy specimens using a validated, automated immunohistochemical assay (Dako North America, Inc., Carpenteria, CA, USA) using a rabbit anti-human PD-L1 antibody (clone 22C3, Dako). Immunohistochemical staining was conducted on 1- $\mu \mathrm{m}$ thick sections of formalin-fixed paraffin embedded (FFPE) tumor blocks according to manufacturer's protocol on Ventana Benchmark Ultra (Ventana Medical Systems, Inc. Tucson, AZ, USA) (14).

Biopsies with at least 100 tumor cells in each section were analyzed and were grouped into three categories : i) $<1 \%$, ii) $1-49 \%$, and iii) $\geq 50 \%$ of tumor PD-L1 expression.

Statistical analysis. Data are presented as proportions (\%) or mean \pm standard deviation unless otherwise stated. Fisher's exact test or the chi-square test were used for data comparisons. The survival time of patients who were known to be alive at the time of the data update was censored at the date of the last follow-up. The KaplanMeier method was used to calculate OS. Kaplan-Meier curves between the groups were compared using a generalized Wilcoxon test, with the level of statistical significance set at 5\% (2-tailed). All statistical analyses were performed using the SPSS version 22.0 for Windows (IBM Japan, Ltd., Tokyo, Japan).

\section{Results}

Patient background characteristics. The background characteristics of the 79 patients are displayed in Table I. The median age was 70 years (range, $41-86$ years). There were 67 smokers and 12 non-smokers. In terms of ECOG PS, 62 

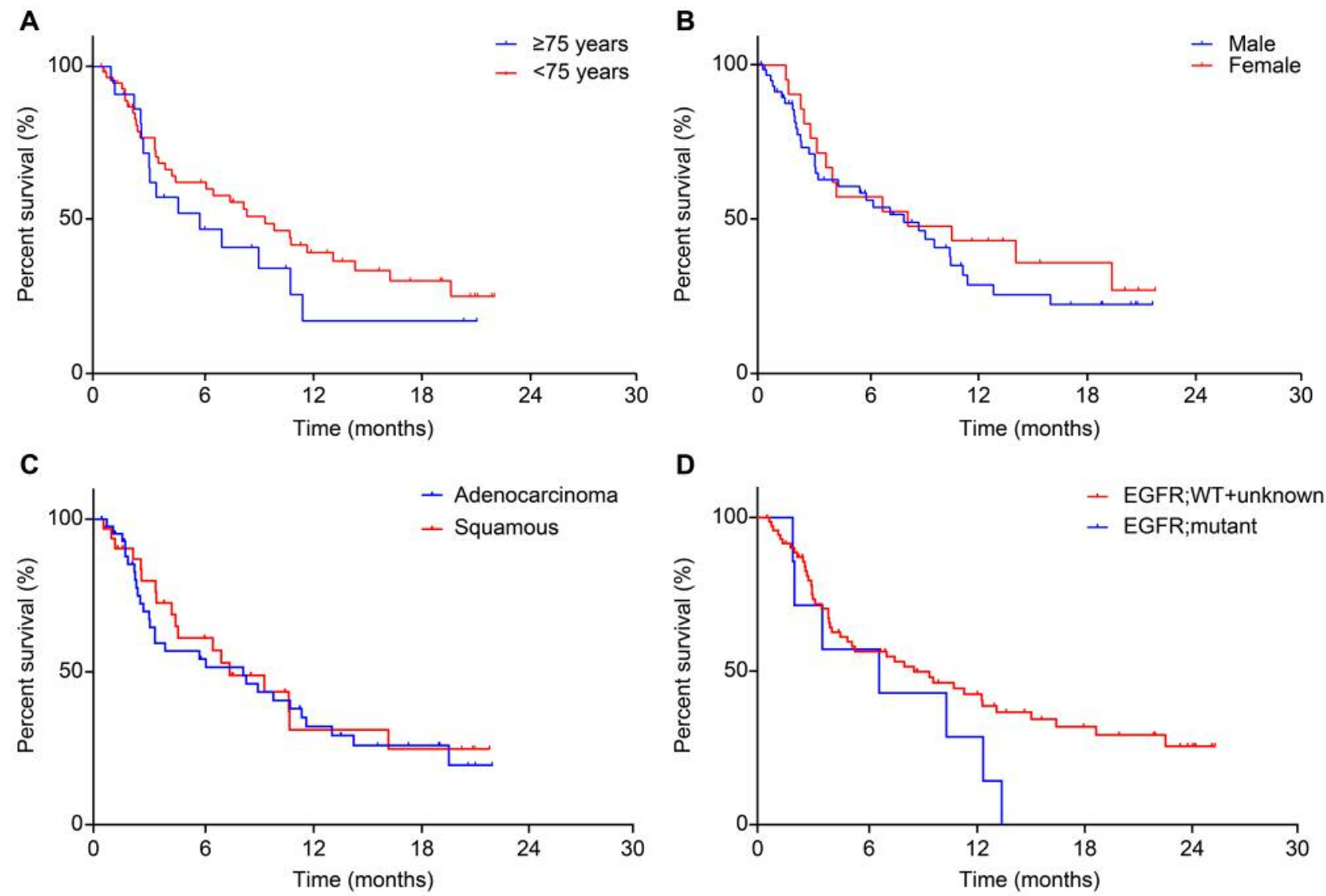

Figure 2. Kaplan-Meier curve for median progression-free survival period with respect to age (a), sex (b), histological classification (c), and epidermal growth factor receptor mutation and wild-type (WT) strain (d).

cases were rated at $0-1$ (PS0, 15; PS1, 47), and 17 cases were rated at $\geq 2$ (PS2, 15; PS3, 2). Histological types included 43 cases of adenocarcinoma, 32 cases of squamous cell carcinoma, and 4 cases of other cancer types.

The median PFS period across all 79 cases was 7.8 months, and the median OS classification was Not Reached (NR) (Figure 1). No significant differences in median PFS period were observed between the groups with respect to age, gender, or histological classification (Figure $2 \mathrm{a}, \mathrm{b}$, and c). In addition, 7 (8.9\%) cases were tested positive for the EGFR gene mutation and $72(91.1 \%)$ cases were classified as wildtype or unknown. The presence or absence of EGFR mutation had no significant difference in the median PFS period (Figure 2d). Regarding the smoking history and PS, smokers exhibited a significantly longer median PFS compared to nonsmokers ( $p=0.0031$ : smokers: 8.5 months; non-smokers: 2.5 months) (Figure 3a). In addition, cases of PS0-1 exhibited a significantly longer median PFS compared to cases of PS 2 ( $p=0.0025$ : PS0-1: 8.9 months; PS2: 2.4 months) (Figure 3b). Adverse events. The AEs observed in the 79 subjects participating in this study are described in Table II. Regarding grade 1-2 AEs, skin rash was observed in 14 $(17.7 \%)$ cases. The skin rash $(+)$ group exhibited significantly longer PFS $(p=0.0016)$ and OS $(p=0.0036)$ periods than the skin rash (-) group (Figure $4 \mathrm{a}$ and $b$ ). The more clinically relevant grade 3-4 AEs developed in 5/79 $(6.3 \%)$ of all cases, and although there were no cases of hematological toxicities, other types of toxicities occurred. These included $2(2.5 \%)$ cases that presented with diarrhea, $2(2.5 \%)$ cases with interstitial lung disease, and $1(1.3 \%)$ case with liver dysfunction. No cases of febrile neutropenia or treatment-related mortality were recorded.

Nivolumab was discontinued in 61 cases either due to $\mathrm{AE}$ or primary disease deterioration. Such large number of discontinued cases could have resulted due to administration of nivolumab as a $3 \mathrm{rd}$ or a later-line treatment. Out of the total cases $(n=61)$ in which the administration of nivolumab was discontinued, those that were due to AEs $(10 / 61 ; 16.4 \%)$ exhibited a significantly prolonged PFS compared to those that were due to a primary disease deterioration $(51 / 61 ; 83.6 \%)$ 

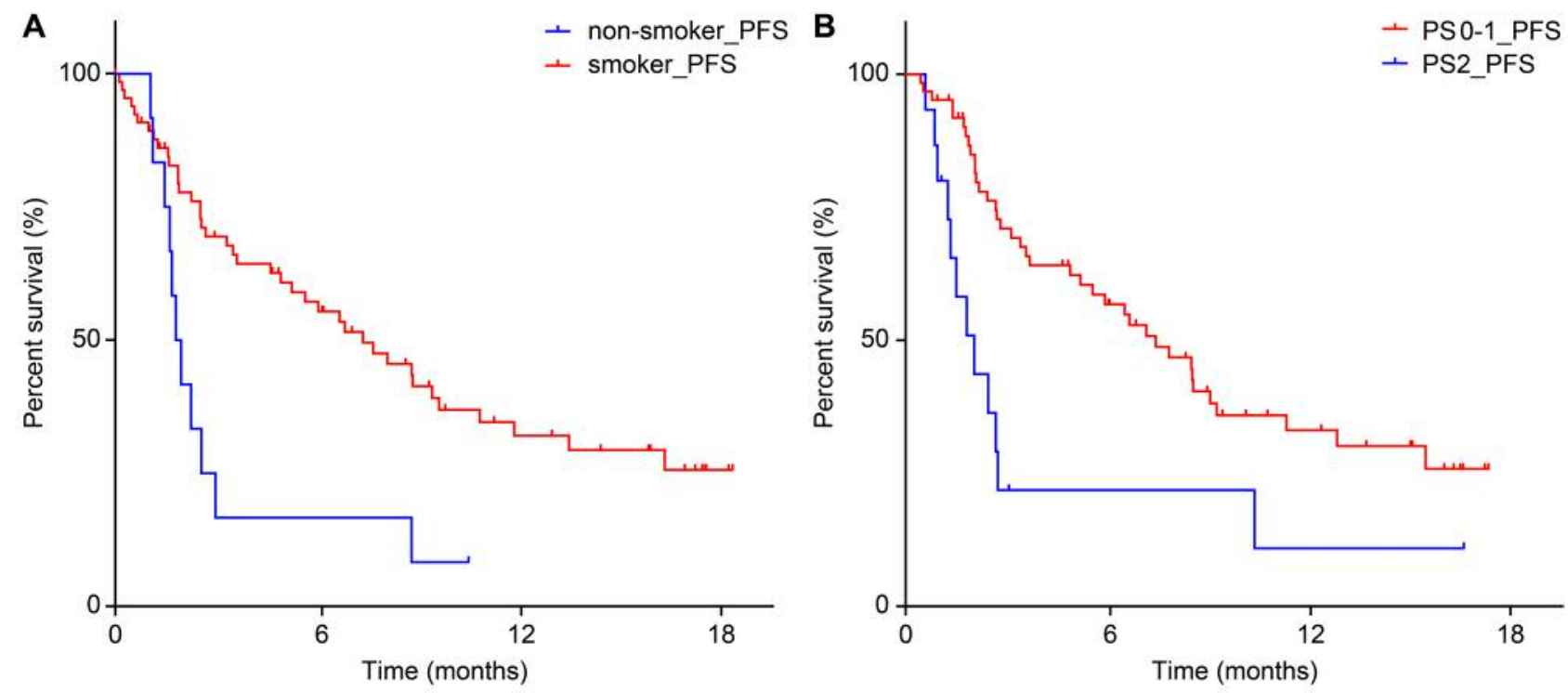

Figure 3. Comparison of progression-free survival (PFS) between non-smokers and smokers (a). Comparison of PFS for patients with a performance status $(P S)$ score of $0-1$ and $2(b)$.

(PFS in the primary disease deterioration $v s$. the AE-related discontinued treatment group; $p=0.0025)$. PFS in the primary disease deterioration-related discontinued treatment group was 3.3 months. Regarding OS, no significant difference was observed between these two groups $(p=0.3447)$. OS for the primary disease deterioration-related discontinued treatment group was 16.5 months (Figure $5 \mathrm{a}$ and $\mathrm{b}$ ).

Treatment results. The results of treatment for each of the 79 subjects are described in Table III. Regarding the tumor shrinkage response, response rate (RR) was obtained in $23 / 79(29.1 \%)$ cases, and disease control rate (DCR) was obtained in $58 / 79(73.4 \%)$ cases. Similar or better outcomes emerged from the treatment with nivolumab in our study as compared to ONO-4538-05, ONO-4538-06, CheckMate 017 and CheckMate 057 trials (Table IV) (5-8). In addition, patients who were smokers and had squamous cell carcinoma exhibited a higher response rate. (RR: Smokers vs. Nonsmokers: $32.8 \%$ vs. $8.3 \%$; RR: All vs. Squamous cell carcinoma: $29.1 \%$ vs. $40.6 \%$ )

The antitumoral effect of each treatment during the course was evaluated as i) the response rate (2nd, $38.3 \%$; $3 \mathrm{rd}$, $23.1 \%$; 4 th and greater, $10.5 \%)$, ii) the disease control rate (2nd, 70.2\%; 3rd, 84.6\%; 4th and greater, 84.2\%), and iii) the median PFS period (2nd, 7.1 months; 3rd, 10.1 months; 4th and greater, 7.8 months) (Table V). No significant differences were observed between the different treatment lines, suggesting that good anti-tumor efficacy can be obtained even at the $3 \mathrm{rd}$, 4th line of treatment or at later ones, if favorable parameters, like PS, show improvement.
Additionally, the breakdown of the pre-treatment responses prior to the administration of nivolumab across all 79 patients was as follows: i) partial remission (PR), 34/79 (43\%); ii) stable disease (SD), 30/79 (38\%); and iii) progressive disease (PD), 15/79 (19\%).

The median PFS periods per pre-treatment response classification were: i) 18.4 for PR, ii) 7.1 for SD, and iii) 3.2 months for PD. Moreover, patients in the pre-treatment PR group exhibited significantly longer PFS periods compared to SD and PD groups (hazard ratio, 0.2691; 95\% confidence interval, 0.06545-0.4009; $p=0.0001$ ) (Figure 6).

PD-L1 subgroup analysis. Although the level of PD-L1 protein expression was confirmed in 18 subjects, no significant differences in OS and PFS were observed between the groups with the three levels of expression. (PFS: $\geq 50 \% / 1-49 \% /<1 \%=2.1 / 6.2 / 2.5$ (months); OS: $\geq 50 \% / 1-49 \% /$ $<1 \%=$ Not reached (NR)/8.5/19.4 (months)).

\section{Discussion}

In this study, we determined the safety and efficacy of nivolumab in a clinical setting. Our results showed similar or better rates of efficacy and safety of nivolumab compared to previously reported results in large-scale clinical trials (6, 13). We considered the possibility that a favorable PS as well as the smoking history of patients $(0-1 / \geq 2,62 / 17$ cases; $\mathrm{Y} / \mathrm{N}$, $67 / 12$ cases, respectively) could serve as predictive response factors. Compared to previous reports these factors posed significant differences in PFS or OS. Age (75-years-old or 

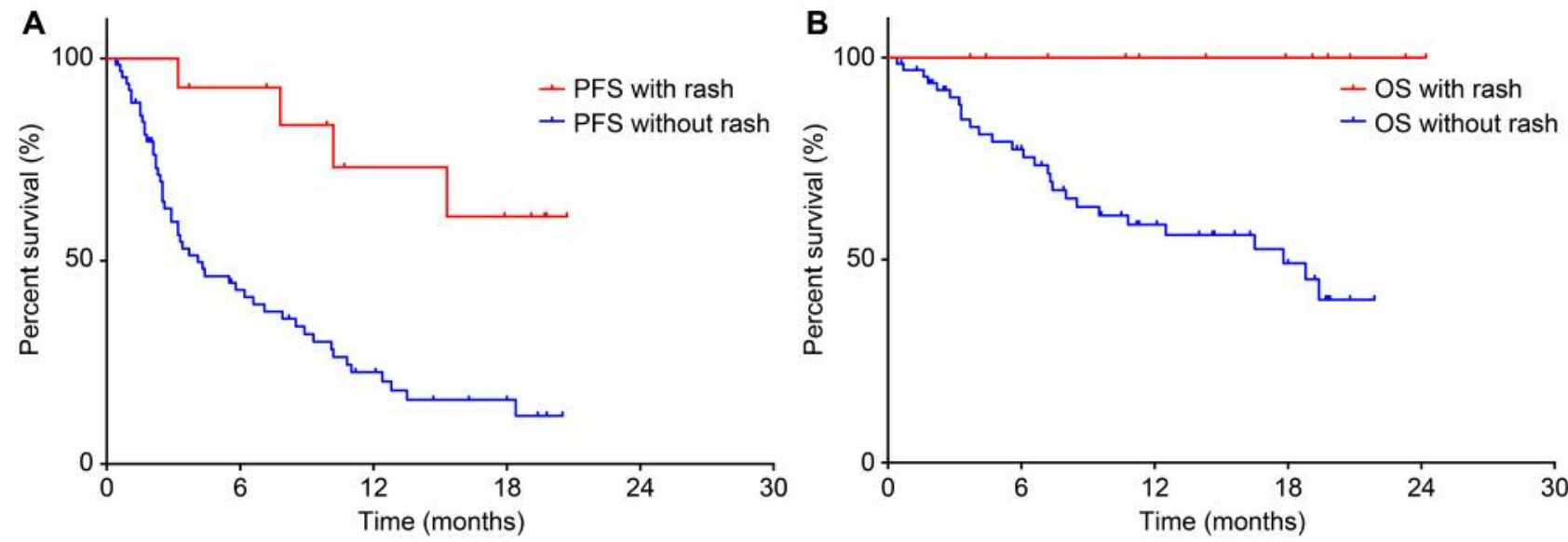

Figure 4. Comparison of progression-free survival (PFS) (a) and overall survival (OS) periods (b) between patients with and without skin rash.
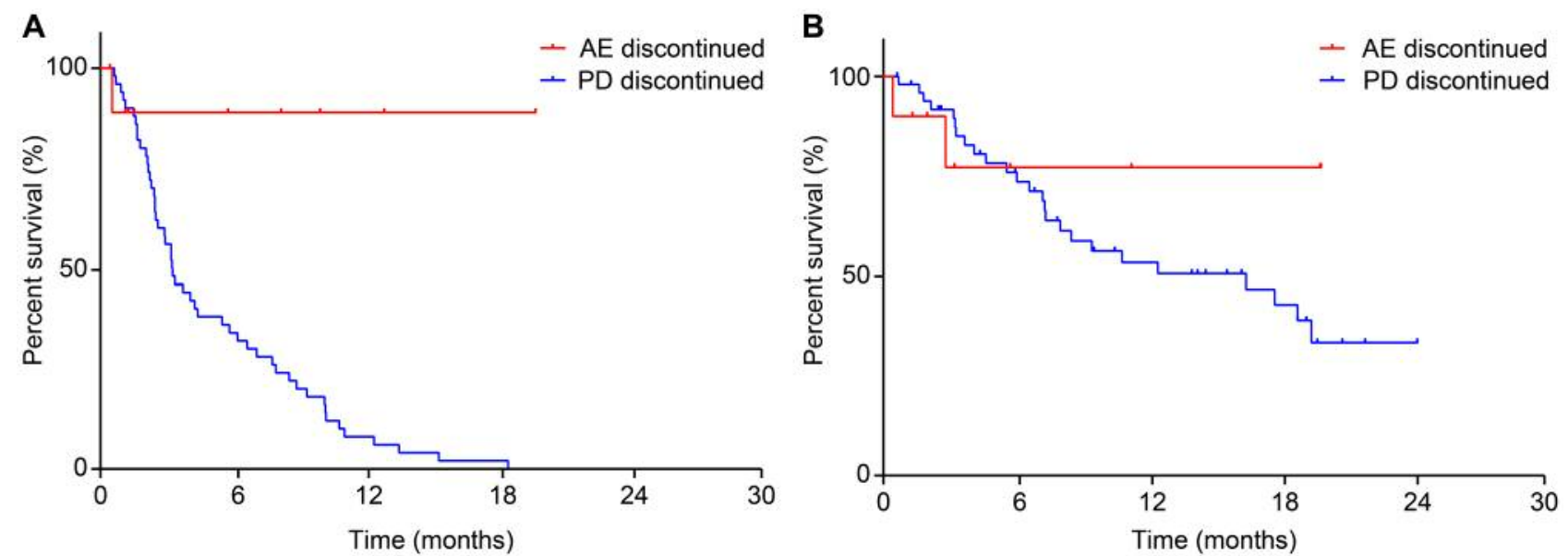

Figure 5. Comparison of progression-free survival (a) and overall survival periods (b) between groups discontinued from nivolumab due to adverse events and progressive disease.

younger), histological type, PD-L1 staining, or EGFR mutation status did not significantly affect the treatment outcome. PFS increased in skin rash (+) group compared to skin rash (-) group.

Although $40 \%$ or more of the total number of cases analyzed in the study used nivolumab as a 3 rd or a later line treatment, the 1-year survival rate was comparable to that reported by Freeman-Keller et al. using nivolumab alone or in combination with a peptide vaccine (16). In addition, the presence of irAEs has been suggested as a risk factor for predicting the therapeutic effect of ipilimumab or nivolumab in cases of melanoma (16). In the current study, only 5 subjects with NSCLC presented with AEs of grade 3-4 and PFS was significantly prolonged in the skin rash group versus the non-skin rash group. Our findings are in line with previous reports of increased survival of NSCLC patients experiencing irAEs after immunotherapy $(17,18)$.

Regarding chemotherapy, Schvartsman et al. have reported a better ORR for chemotherapy immediately after the administration of nivolumab as compared to historical data before the development of immunotherapy (19). Nakahama et al. have showed aa better disease control post nivolumab treatment if pre-nivolumab chemotherapy showed a good clinical response (20). Thus, nivolumab might serve as chemotherapy for prolonging the survival of NSCLC patients.

This study included many cases "unfit for clinical trials," such as patients with poor PS, complicated interstitial pneumonia, organ dysfunction, as well as patients with 


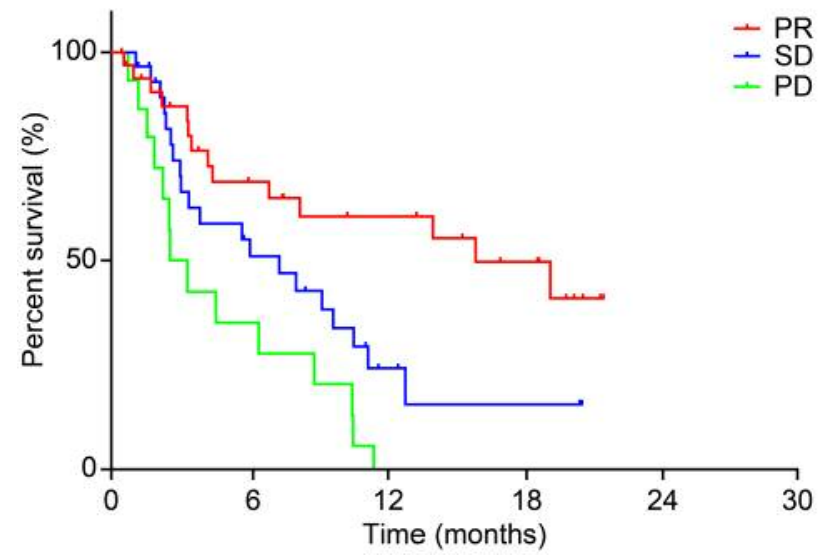

Figure 6. Kaplan-Meier curve for progression-free survival periods of pre-treated patients before Nivolumab. Partial response (PR), stable disease $(S D)$, and progressive disease $(P D)$.
Table II. Incidence of treatment-related $A E$.

\begin{tabular}{|c|c|c|c|c|}
\hline \multirow[t]{2}{*}{ Treatment-related AE $(n=79)$} & \multicolumn{2}{|c|}{ Grade $1-2$} & \multicolumn{2}{|c|}{$\leq$ Grade 3} \\
\hline & $\mathrm{n}$ & $\%$ & $\mathrm{n}$ & $\%$ \\
\hline Rash & 14 & 17.7 & 0 & 0 \\
\hline Hypothyroidism & 6 & 7.6 & 0 & 0 \\
\hline Diarrhea & 2 & 2.5 & 2 & 2.5 \\
\hline ILD & 5 & 6.3 & 2 & 2.5 \\
\hline Edema & 1 & 1.3 & 0 & 0 \\
\hline Adrenal insufficiency & 4 & 5.1 & 0 & 0 \\
\hline Liver damage & 2 & 2.5 & 1 & 1.3 \\
\hline Myopathy & 1 & 1.3 & 0 & 0 \\
\hline Total & 35 & 44.3 & 5 & 6.3 \\
\hline
\end{tabular}

AE, Adverse events; ILD, interstitial lung disease.

Table III. Tumor response in patients with advanced NSCLC treated with nivolumab.

\begin{tabular}{|c|c|c|c|c|c|c|c|c|c|c|c|c|}
\hline & \multicolumn{2}{|c|}{$\begin{array}{c}\text { All } \\
\mathrm{n}=79\end{array}$} & \multicolumn{2}{|c|}{$\begin{array}{l}\text { Adeno-carcinoma } \\
\mathrm{n}=43\end{array}$} & \multicolumn{2}{|c|}{$\begin{array}{c}\text { Squamous } \\
n=32\end{array}$} & \multicolumn{2}{|c|}{$\begin{array}{c}\text { Smoker } \\
n=67\end{array}$} & \multicolumn{2}{|c|}{$\begin{array}{c}\text { Non-smoker } \\
\mathrm{n}=12\end{array}$} & \multicolumn{2}{|c|}{$\begin{array}{c}\text { Mutant } \\
\mathrm{n}=7\end{array}$} \\
\hline & $\mathrm{n}$ & $\%$ & $\mathrm{n}$ & $\%$ & $\mathrm{n}$ & $\%$ & $\mathrm{n}$ & $\%$ & $\mathrm{n}$ & $\%$ & $\mathrm{n}$ & $\%$ \\
\hline $\mathrm{CR}$ & 2 & 2.5 & 0 & 0 & 2 & 6.3 & 2 & 3 & 0 & 0 & 0 & 0 \\
\hline PR & 21 & 26.6 & 9 & 20.9 & 11 & 34.4 & 20 & 29.9 & 1 & 8.3 & 0 & 0 \\
\hline SD & 35 & 44.3 & 21 & 48.8 & 12 & 37.5 & 30 & 44.8 & 5 & 41.7 & 5 & 71.4 \\
\hline $\mathrm{PD}$ & 18 & 22.8 & 13 & 30.2 & 5 & 15.6 & 12 & 17.9 & 6 & 50 & 2 & 28.6 \\
\hline Not evaluated & 3 & 3.8 & 0 & 0 & 2 & 6.3 & 3 & 4.5 & 0 & 0 & 0 & 0 \\
\hline Response rate & \multicolumn{2}{|c|}{$29.10 \%$} & \multicolumn{2}{|c|}{$20.90 \%$} & \multicolumn{2}{|c|}{$40.60 \%$} & \multicolumn{2}{|c|}{$32.80 \%$} & \multicolumn{2}{|c|}{$8.30 \%$} & \multicolumn{2}{|c|}{$0 \%$} \\
\hline Disease control rate & \multicolumn{2}{|c|}{$73.40 \%$} & \multicolumn{2}{|c|}{$69.70 \%$} & \multicolumn{2}{|c|}{$78.10 \%$} & \multicolumn{2}{|c|}{$77.60 \%$} & \multicolumn{2}{|c|}{$50.00 \%$} & \multicolumn{2}{|c|}{$66.70 \%$} \\
\hline
\end{tabular}

CR, Complete response; NSCLC, non-small cell lung cancer; PD, progressive disease; PR, partial response; SD, stable disease.

Table IV. Nivolumab trials.

\begin{tabular}{|c|c|c|c|c|c|}
\hline & Present study & ONO-4538-05 & ONO-4538-06 & CheckMate017 & CheckMate 057 \\
\hline Trial & Retrospective & Phase II & Phase II & Phase III & Phase III \\
\hline Control Arm & none & none & none & Docetaxel & Docetaxel \\
\hline Objective & $\begin{array}{l}\text { advanced or } \\
\text { recurrent NSCLC }\end{array}$ & $\begin{array}{l}\text { advanced or } \\
\text { recurrent } \mathrm{Sq}\end{array}$ & $\begin{array}{l}\text { advanced or } \\
\text { recurrent non-Sq }\end{array}$ & $\begin{array}{l}\text { advanced or } \\
\text { recurrent } \mathrm{Sq}\end{array}$ & $\begin{array}{l}\text { advanced or } \\
\text { recurrent non-Sc }\end{array}$ \\
\hline Cases & 79 & 35 & 76 & 272 & 582 \\
\hline Dose & $3 \mathrm{mg} / \mathrm{kg} / 2 \mathrm{~W}$ & $3 \mathrm{mg} / \mathrm{kg} / 2 \mathrm{~W}$ & $3 \mathrm{mg} / \mathrm{kg} / 2 \mathrm{~W}$ & $3 \mathrm{mg} / \mathrm{kg} / 2 \mathrm{~W}$ & $3 \mathrm{mg} / \mathrm{kg} / 2 \mathrm{~W}$ \\
\hline \multicolumn{6}{|l|}{ Primary } \\
\hline Endpoints & Retrospective & ORR & ORR & OS & OS \\
\hline ORR & $29.1 \%$ & $25.7 \%$ & $22.4 \%$ & $20 \%$ vs. $9 \%$ & $19 \%$ vs. $12 \%$ \\
\hline PFS & 7.8 months & 4.2 months & 2.8 months & $\begin{array}{l}3.5 \text { months } v s . \\
2.8 \text { months }\end{array}$ & $\begin{array}{l}2.3 \text { months } v s \text {. } \\
4.2 \text { months }\end{array}$ \\
\hline OS & NR & 16.3 months & 17.1 months & $\begin{array}{l}9.2 \text { months } v s \text {. } \\
6.0 \text { months }\end{array}$ & $\begin{array}{c}12.2 \text { months } \\
\text { vs. } 9.4 \text { months }\end{array}$ \\
\hline 1-year survival & $40.5 \%$ & $71.4 \%$ & $68.0 \%$ & $42 \%$ vs. $24 \%$ & $51 \%$ vs. $39 \%$ \\
\hline $\mathrm{G} 3 / 4(\%)$ & $6.3 \%$ & $5.7 \%$ & $22.4 \%$ & $7 \%$ vs. $55 \%$ & $10 \%$ vs. $54 \%$ \\
\hline
\end{tabular}

NSCLC, Non-small cell lung cancer; NR, not reached; ORR, overall response rate; OS, overall survival; PFS, progression-free survival; Sq, squamous; $\mathrm{W}$, weeks. 
Table V. Baseline characteristics with prior treatment $(N=79)$.

\begin{tabular}{lccc}
\hline & \multicolumn{3}{c}{$\begin{array}{c}\text { Tumor response to nivolumab } \\
\text { used as differing lines of therapy }\end{array}$} \\
\cline { 2 - 4 } & 2nd line (N) & 3rd line (N) & $\geq 4$ th line (N) \\
\hline PR & 18 & 3 & 2 \\
SD & 15 & 8 & 12 \\
PD & 12 & 2 & 4 \\
NE & 2 & 0 & 1 \\
Total (N/\%) & $47(59.5)$ & $13(16.5)$ & 19.5 \\
ORR (\%) & 38.3 & 23.1 & 84.2 \\
DCR (\%) & 70.2 & 84.6 & 7.8 \\
PFS (Months) & 7.1 & 10.1 & 10.0 \\
\hline
\end{tabular}

PR, Partial response; SD, stable disease; PD, progressive disease; NE, not evaluable; ORR, overall response rate; DCR, Disease Control Rate; PFS, progression-free survival.

multiple cancers. All these elements are difficult to incorporate into generalized clinical trials. Thus, evidence obtained through clinical trials cannot be applied without consideration of such elements when treating patients in the clinical practice.

There are certain limitations inherent to this study. First, the lack of PD-L1 evaluation in post-treatment samples could be problematic. Second, the lack of available follow-up data may have introduced a degree of bias in our analyses. Both these limitations are due to the retrospective nature of the study and restrict our interpretations. In addition, we were unable to ascertain multiple AEs in certain patients. Further retrospective studies, as well as carefully planned prospective studies, will be useful to validate our findings in clinical practice.

In conclusion, long-term survival may be possible for NSCLC patients with skin rash. Furthermore, the therapeutic effect of nivolumab immediately following its administration appeared to be favorable for the survival of these patients. These clinical practice-based insights should be taken into consideration when choosing nivolumab to control tumor growth and achieve long-term survival for NSCLC patients.

\section{Acknowledgements}

Editorial support in the form of medical rewriting was provided by Cactus Communications. This research was not supported by any specific grant from funding agencies in the public, commercial, or not-for-profit sectors.

\section{Conflict of Interest}

The Authors have no conflicts of interest to declare regarding the contents of this article.

\section{References}

1 Suzuki S, Ishida T, Yoshikawa K and Ueda R: Current status of immunotherapy. Japanese J Clin Oncol 46(3): 191-203, 2016.

2 Wang C, Thudium KB, Han M, Wang XT, Huang H, Feingersh D, Garcia C, Wu Y, Kuhne M, Srinivasan M, Singh S, Wong S, Garner N, Leblanc H, Bunch RT, Blanset D, Selby MJ and Korman AJ: In vitro characterization of the anti-PD-1 antibody nivolumab, BMS-936558, and in vivo toxicology in non-human primates. Cancer Immunol Res 9: 846-856, 2014.

3 Ettinger DS, Wood DE, Aisner DL, Akerley W, Bauman J, Chirieac LR, D'Amico TA, DeCamp MM, Dilling TJ, Dobelbower M, Doebele RC, Govindan R, Gubens MA, Hennon M, Horn L, Komaki R, Lackner RP, Lanuti M, Leal TA, Leisch LJ, Lilenbaum R, Lin J, Loo BW Jr, Martins R, Otterson GA, Reckamp K, Riely GJ, Schild SE, Shapiro TA, Stevenson J, Swanson SJ, Tauer K, Yang SC, Gregory K and Hughes M: NonSmall Cell Lung Cancer, Version 5 2017, NCCN Clinical Practice Guidelines in Oncology. J Natl Compr Canc Netw 15(4): 504-535, 2017.

4 Carbone DP, Reck M, Paz-Ares L, Creelan B, Horn L, Steins M, Felip E, van den Heuvel MM, Ciuleanu TE, Badin F and Ready $\mathrm{N}$ : First-line nivolumab in stage IV or recurrent non-small-cell lung cancer. N Engl J Med 376(25): 2415-2426, 2017.

5 Brahmer J, Reckamp KL, Baas P, Crino L, Eberhardt W, Poddubskaya E, Antonia S, Pluzanski A, Vokes E, Holgado E, Waterhouse D, Ready N, Gaino J, Fontera OA, Havel L, Steins M, Grassino M, Aerts J, Domine M, Paz-Ares L, Reck M, Baudelet C, Harbison CT, Lestini B and Spigel DR: Nivolumab versus docetaxel in advanced squamous-cell non-small-cell lung cancer. N Engl J Med 9: 123-135, 2015.

6 Borghaei H, Paz-Ares L, Horn L, Spigel DR, Steins M, Ready N, Chow LQ, Vokes EE, Felip E, Holgado E, barlesi F, Kohlhaulf M, Arrieta O, Burgio MA, Fayette J, Lena H, Poddubskaya E, Gerber De, Gettinger Se, Rudin CM, Rizvi N, Crino L, Blumenschein GR, Antonia MD, Dorange C, Harbison CT, Finckenstein FG and Brahmer JR: Nivolumab versus docetaxel in advanced nonsquamous non-small-cell lung cancer. N Engl J Med 22: 1627-1639, 2015.

7 Hida T, Nishio M, Nogami N, Ohe Y, Nokihara H, Sakai H, Satouchi M, Nakagawa K, Takenoyama M, Isobe H, Fujita S, Tanaka H, Minato K, Takahashi T, Maemondo M, Takeda K, Saka H, Goto K, Atagi S, Hirashima T, Sumiyoshi N and Tamura $\mathrm{T}$ : Efficacy and safety of nivolumab in Japanese patients with advanced or recurrent squamous non-small cell lung cancer. Cancer Sci 108: 1000-1006, 2017.

8 Nishio M, Hida T, Atagi, Sakai H, Nakagawa K, Takahashi T, Nogami N, Saka H, Takenoyama M, Maemondo M, Ohe Y, Nokihara H, Hirashima T, Tanaka H, Fujita S, Takeda K, Goto $\mathrm{K}$, Satouchi M, Isobe $\mathrm{H}$, Minato K, Sumiyoshi N and Tamura T: Multicentre phase II study of nivolumab in Japanese patients with advanced or recurrent non-squamous non-small cell lung cancer. ESMO Open 7: e000108, 2017.

9 Chen TW, Razak AR, Bedard PL, Siu LL and Hansen AR: A systematic review of immune-related adverse event reporting in clinical trials of immune checkpoint inhibitors. Annals Oncol 26: 1824-1829, 2015.

10 Weber JS, Postow M, Lao CD and Schadendorf D: Management of adverse events following treatment with anti-programmed death-1 agents. The Oncologist 21: 1230-1240, 2016. 
11 Kuribayashi K, Funaguchi $\mathrm{N}$ and Nakano T: Chemotherapy for advanced non-small cell lung cancer with a focus on squamous cell carcinoma. J Cancer Res Ther 12: 528-534, 2016.

12 Eisenhauer EA, Therasse P, Bogaerts J, Schwartz LH, Sargent D, Ford R, Dancey J, Arbuck S, Gwyther S, Mooney M, Rubinstein L, Shankar L, Dodd L, Kaplan R, Lacombe D and Verweij J: New response evaluation criteria in solid tumours: revised RECIST guideline (version 1.1). European J Cancer 45: 228-247, 2009.

13 US Department of Health and Human Services: Common terminology criteria for adverse events (CTCAE) version 4.0. National Cancer Institute (09-5410). 2009.

14 Erber R, Stöhr R, Herlein S, Giedl C, Rieker RJ, Fuchs F, Ficker JH, Hartmann A, Veltrup E, Wirtz RM and Brueckl WM: Comparison of PD-L1 mRNA expression measured with the CheckPoint Typer $^{\circledR}$ assay with PD-L1 protein expression assessed with immunohistochemistry in non-small cell lung cancer. Anticancer Res 37(12): 6771-6778, 2017

15 Tumeh, PC, Harview, CL, Yearley, JH, Shintaku IP, Taylor EJ, Robert L, Chmielowski B, Spasic M, Henry G, Ciobanu V, West AN, Carmona M, Kivork C, Seja E, Cherry G, Gutierrez AJ, Grogan TR, Mateus C, Tomasic G, Glaspy JA, Emerson RO, Robins H, Pierce RH, Elashoff DA, Robert C and Ribas A: PD1 blockade induces responses by inhibiting adaptive immune resistance. Nature 515: 568-571, 2014.

16 Freeman-Keller M, Kim Y, Cronin H, Richards A, Gibeny G and Weber JS: Nivolumab in resected and unresectable metastatic melanoma: Characteristics of immune-related adverse events and association with outcomes. Clin Cancer Res 22: 886-894, 2016.
17 Haratani K, Hayashi H, Chiba Y, Kudo K, Yonesaka K, Kato R, Kaneda H, Hasegawa Y, Tanaka K, Takeda M and Nakagawa K: Association of immune-related adverse events with nivolumab efficacy in non-small-cell lung cancer. JAMA Oncol 4: 374-378, 2017.

18 Teraoka S, Fujimoto D, Morimoto T, Kawachi H, Ito M, Sato Y, Nagata K, Nakagawa A, Otsuka K, Uehara K, Imai Y, Ishida K, Fukuoka $\mathrm{J}$ and Tomii K: Early immune-related adverse events and association with outcome in advanced non-small cell lung cancer patients treated with nivolumab: A prospective cohort study. J Thorac Oncol 12: 1798-1805, 2017.

19 Schvartsman G, Peng SA, Bis G, Lee JJ, Benveniste MFK, Zhang J, Roarty EB, Lacerda L, Swisher S, Heymach JV, Fossella FV and William WN: Response rates to single-agent chemotherapy after exposure to immune checkpoint inhibitors in advanced non-small cell lung cancer. Lung Cancer 7: 90-95, 2017.

20 Nakahama K, Isa SI, Tamiya A, Taniguchi Y, Shiroyama T, Suzuki $\mathrm{H}$, Inoue $\mathrm{T}$, Tamiya $\mathrm{M}$, Hirashima $\mathrm{T}$, Imamura $\mathrm{F}$ and Atagi S: The association between chemotherapy immediately before nivolumab and outcomes thereafter. Anticancer Res 37(10): 5885-5891, 2017.

Received October 11, 2018

Revised December 25, 2018

Accepted January 7, 2019 